American Journal of Psychiatric Research and Reviews (ISSN:2637-479X)

\title{
SOCIAL DISAPPROVAL AS A FACTOR OF VULNERABILITY TO MENTAL ILLNESS IN SEXUAL AND GENDER MINORITIES
}

Leilane Camila Ferreira de Lima Francisco ${ }^{1 *}$, Alice Correia Barros ${ }^{1}$, Izabelly Carollynny Maciel Nunes $^{2}$, Jéssica Diodino da Silva Santos ${ }^{2}$, Jaqueline Michelle da Conceição Alexandre ${ }^{2}$, Verônica de Medeiros Alves ${ }^{3}$

${ }^{1}$ Enfermeira. Especialista em Psiquiatria e Saúde Mental. Mestranda em enfermagem pela Universidade Federal de Alagoas. Membro do grupo de estudos em saúde mental, álcool e outras drogas da Universidade Federal de Alagoas. ${ }^{2}$ Acadêmica de enfermagem pela Universidade Federal de Alagoas. Membro do grupo de estudos em saúde mental, álcool e outras drogas da Universidade Federal de Alagoas. ${ }^{3}$ Docente do curso de Enfermagem da Universidade Federal de Alagoas, Mestre em Ciências da Saúde, Doutora em Saúde Mental pelo Instituto de Psiquiatria da UFRJ.

\section{ABSTRACT}

Introduction: The population of Lesbians, Gays, Bisexual, Transvestite and Transsexual is the target of social failure (Homophobias, Lesbophobia, transphobia), which contributes to social exclusion and with great association with vulnerability to their health and suffering. Objective: To identify the prevalence of social failure as a factor of vulnerability to mental illness in sexual and gender minorities. Methodology: This is a descriptive, transversal and quantitative study. Data collection took place between December 2018 and June 2019. The place where the research occurred was the Federal University of Alagoas. The instruments used were the identification questionnaire and the Mini International Neuropsychiatric Interview. Students belonging to sexual and gender minorities who studied at the Federal University of Alagoas, aged 18 years and over, were included. Those who gave up graduation during data collection were excluded. The research was approved by the Research Ethics Committee of the Federal University of Alagoas. Results: 141 students belonging to sex and gender minorities were interviewed, 64 (45.4\%) female and $77(54.6 \%)$ male sex. Regarding sexual orientation, $83(58.9 \%)$ were homosexuals, 50 (35.5\%) were bisexual and $8(5.8 \%)$ pansexuals. In relation to gender identity, $135(95.7 \%)$ were cisgender, $2(1.4 \%)$ were transgendered and $4(2.8 \%)$ non-binary. $139(98.6 \%)$ Individuals had already revealed their sexual orientation to someone. Of these, $112(79.4 \%)$ already suffered social failure, being $74(52.5 \%)$ from the family, $56(39.7 \%)$ from unknown persons, 21 $(14.9 \%)$ from friends, $12(8.5 \%)$ from college colleagues and $10(7.1 \%)$ from co-workers. According to MINI, 134 (95\%) who had some kind of mental disorder, $89(63.1 \%)$ presented generalized anxiety disorder. In addition, of the total number of respondents, 108 (76.6\%) had psychiatric comorbidities. Conclusions: The research data identified that sexual and gender minorities are vulnerable to mental illness, highlighting generalized anxiety disorder, reflecting all social and family pressures that these individuals suffer to adapt to gender standards and norms, in addition to the whole context of coping with life that affects negative consequences for the mind and body. It is necessary to create care strategies that promote the well-being and improvement of the mental health of this population.

Keywords: Social stigma, Mental disorders, Sex and gender minorities.

*Correspondence to Author:

Mateus Cotias Filizola

Estudante do Curso de Medicina da Universidade Federal de Pernambuco - UFPE

How to cite this article:

Leilane Camila Ferreira de Lima Francisco, Alice Correia Barros, Izabelly Carollynny Maciel Nunes, Jéssica Diodino da Silva Santos, Jaqueline Michelle da Conceição Alexandre, Verônica de Medeiros Alves. SOCIAL DISAPPROVAL AS A FACTOR OF VULNERABILITY TO MENTAL ILLNESS IN SEXUAL AND GENDER MINORITIES American Journal of Psychiatric Research and Reviews, 2020, 3:13

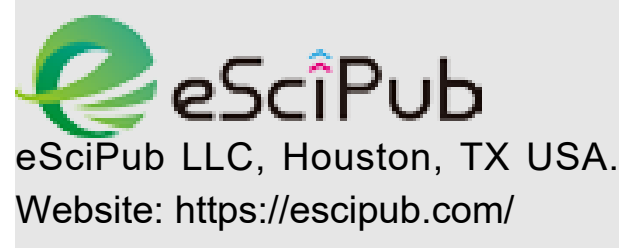

